Noble Nationalists 



\section{Noble Nationalists}

THE TRANSFORMATION OF

THE BOHEMIAN ARISTOCRACY

Eagle Glassheim

HARVARD UNIVERSITY PRESS

Cambridge, Massachusetts

London, England 2005 
Copyright (C) 2005 by the President and Fellows of Harvard College All rights reserved

Printed in the United States of America

Library of Congress Cataloging-in-Publication Data

Glassheim, Eagle.

Noble nationalists : the transformation of the Bohemian aristocracy /

Eagle Glassheim.

p. $\mathrm{cm}$.

Includes bibliographical references and index.

ISBN 0-674-01889-3 (alk. paper)

1. Bohemia (Czech Republic)-Politics and government-1848-

1918. 2. Czech Republic-Politics and government-20th century.

3. Nobility-Czech Republic-History. 4. Nationalism-Czech Republic-History. I. Title.

DB2178.7.G59 2005

943.71'024-dc22

2005046322 